\title{
MORTALITY AND MORBIDITY PATTERN OF SEVERE AND MODERATE PRETERM BABIES IN A TERTIARY CARE HOSPITAL IN KERALA- A RETROSPECTIVE RECORD BASED STUDY.
}

\author{
Sindhu Thomas Stephen ${ }^{1}$, Peter Pathrose Vazhayil2, Nahala Puliyulla Kandi ${ }^{3}$
}

${ }^{1}$ Assistant Professor, Department of Paediatrics, Government Medical College, Ernakulam, Kerala.

${ }^{2}$ Associate Professor, Department of Paediatrics, Government Medical College, Ernakulam, Kerala.

3Junior Resident, Department of Paediatrics, Government Medical College, Ernakulam, Kerala.

\section{ABSTRACT}

\section{BACKGROUND}

Babies of the gestational age group 28 - 34 weeks (Moderate-to-Severe Preterm) constitute a major proportion of preterm births, and in a country like ours they have better outcome in terms of mortality, morbidity, long-term adverse consequences and financial implications when compared to extreme preterm $(<28$ weeks) babies. Therefore, surveying of these babies is a need for planning interventional strategies to reduce neonatal mortality and morbidity rate.

\section{MATERIALS AND METHODS}

This is a retrospective, observational, record-based study done in the Department of Neonatology, Government Medical College, Ernakulam over a period of 3 years. All preterm babies in the gestation $28^{+0}$ to $33^{+6}$ weeks admitted to the Neonatal Intensive Care Unit (NICU) during the period were included in the study. The main outcome measures were major morbidities prior to hospital discharge.

\section{RESULTS}

There were 2491 deliveries during the study period, of which preterm deliveries (< 37 weeks) constituted $20.75 \%$. The incidence of inborn preterm delivery in the gestation $28^{+0}-33^{+6}$ weeks was 50 per 1000 live births $(5.02 \%)$. Severe preterm babies $\left(28^{+0}-\right.$ $31^{+6}$ weeks) constituted $(48.72 \%)$ with mean weight of $1.29 \pm 0.27 \mathrm{~kg}$ and moderate preterms $\left(32^{+0}-33^{+6}\right)$ constituted $(51.28 \%)$ with mean weight of $1.72 \pm 0.35 \mathrm{~kg}$. The mortality in the study group was only $(4.48 \%)$. Hyperbilirubinaemia was the most common morbidity (63.46 \%) followed by respiratory distress syndrome (58.33\%) and blood culture positive Sepsis (27.56\%). Other morbidities in the study population included apnoea $(14.74 \%)$, retinopathy of prematurity $(12.82 \%)$, anaemia $(9.61 \%)$, meningitis (8.97\%) and acute kidney injury (8.97\%). Necrotising enterocolitis was seen in 7.69\%, seizures in 5.13\%, intraventricular haemorrhage in $4.49 \%$ and birth asphyxia in $2.56 \%$.

\section{CONCLUSION}

Preterm birth still continues to be a major problem in our setup. Respiratory distress syndrome being a major cause of morbidity in the study group, antenatal measures to improve lung maturity can have an important role in better outcome.

\section{KEYWORDS}

Preterm Babies, Mortality, Morbidity, Gestational Age, Neonatal Outcome.

HOW TO CITE THIS ARTICLE: Stephen ST, Vazhayil PP, Kandi NP. Mortality and morbidity pattern of severe and moderate preterm babies in a tertiary care hospital in Kerala- A Retrospective record based study. J. Evolution Med. Dent. Sci. 2018;7(13): 1625-1629, DOI: $10.14260 / \mathrm{jemds} / 2018 / 368$

\section{BACKGROUND}

Prematurity (birth occurring before 37 weeks gestation) is an important determinant of neonatal mortality and morbidity and has long-term adverse effects on the growth and development of a baby.(1) It is one of the leading causes of neonatal deaths, accounting for about $24 \%-28 \% .{ }^{(2)}$ Although, recent advances in perinatal care, use of antenatal corticosteroids, postnatal surfactant therapy and availability of modern ventilator techniques have led to markedly improved survival of premature infants, disorders related to short gestation and low birth weight are still significant causes of infant morbidity and mortality. (3)

'Financial or Other Competing Interest': None.

Submission 13-02-2018, Peer Review 10-03-2018,

Acceptance 16-03-2018, Published 26-03-2018.

Corresponding Author:

Dr. Peter Pathrose Vazhayil,

Associate Professor,

Department of Paediatrics, Government Medical College,

Kalamassery, Ernakulam-683503, Kerala.

E-mail:drpeter123@yahoo.com

DOI: $10.14260 /$ jemds $/ 2018 / 368$

Preterm birth is further classified as extreme preterm, ( $<28$ weeks) severe preterm $\left(28^{+0}-31^{+6}\right.$ weeks), moderate preterm $\left(32^{+0}-33^{+6}\right.$ weeks $)$ and late preterm $\left(34^{+0}-36^{+6}\right.$ weeks). $(4,5)$ The risks of extreme preterm birth (before 28 weeks' gestation) have been extensively studied. It is well documented that delivery at this very early stage of pregnancy is associated with substantial risk to the newborns with adverse long-term outcomes in later life.(6) Late preterm babies have also been the main focus of perinatal research over the recent years. In contrast, babies born between 28 and 34 weeks gestation have been understudied and indeed they stand in the brim in terms of mortality and morbidity. These infants also constitute a much larger group than extreme preterm infants, representing $6 \%-7 \%$ of all births and around $75 \%$ of preterm births which is increasing disproportionately in recent years.(7) As such there is a relative paucity of data about the outcomes of these larger and more mature preterm infants. Therefore, it is a time felt need to analyse at the current profile of preterm births in this particular gestational age group. Moreover, clinicians require up-to-date information about the incidence of prematurity, morbidity and mortality from within their regions, which will 
help to provide accurate counselling, anticipate complications during NICU stay as well as facilitate review of local policies which will help to improve the outcomes.

Our study attempts to look at the morbidity and mortality profile of babies in the gestational age group of $28^{+0}-33^{+6}$ weeks.

\section{MATERIALS AND METHODS}

This is a descriptive, record-based study, conducted in the NICU of Government Medical College, Ernakulam over a period of 3 years. We retrospectively evaluated our neonatal database and case records of all preterm babies $\left(28^{+0}\right.$ to $33^{+6}$ weeks) admitted to the NICU during the period $1^{\text {st }}$ June 2014 to $31^{\text {st }}$ May 2017. All still births, IUD and major congenital anomalies were excluded from the study. The relevant data was collected using a standard proforma, which included a range of details like mode of delivery, birth order, gestational age, birth weight, gender, Apgar score, resuscitation details, mortality (Table 1), pre-discharge morbidity in the survivors (Table 2) and management during hospitalisation (Table 3). While some variables in the proforma are self-explanatory, definitions for other relevant major variables are as follows-

\section{Intraventricular Haemorrhage (IVH):}

The severity of IVH using Papile Classification seen on the head ultrasound imaging.(8)

\section{Retinopathy of Prematurity (ROP)}

Described by the Committee for Classification of ROP.(9)

\section{Respiratory Distress Syndrome (RDS)}

Presence of tachypnoea, retractions and grunting supported by chest $\mathrm{x}$-ray finding.(10)

\section{Chronic Lung Disease (CLD)}

Any respiratory support at 36 weeks corrected age.(11)

\section{Early-Onset Sepsis}

Clinical picture consistent with sepsis within the first $48 \mathrm{~h}$ of life and a positive bacterial or fungal culture of blood and/or cerebrospinal fluid.

\section{Late-Onset Sepsis}

Clinical picture consistent with sepsis after the first $48 \mathrm{~h}$ of life and a positive bacterial or fungal culture of blood and/ or cerebrospinal fluid.

\section{Meningitis}

Biochemical or culture positive CSF.

Birth Asphyxia- Apgar $\leq 3$ at 5 minutes.

\section{Hypoglycaemia}

At least one recording of random blood sugar by glucose strips $<45 \mathrm{mg} \%{ }^{(12)}$

\section{Acute Kidney Injury (AKI)}

Serum Creatinine $\geq 1.5 \mathrm{mg} / \mathrm{dL}$ or rising value $>0.3$ mg/day.(13)

\section{Hyperbilirubinaemia \\ Requiring conventional phototherapy.(14)}

The data collected in the proforma, numerically coded and entered in Microsoft Excel spread sheet. Further statistical analysis was done using the Statistical Package for Social Sciences (SPSS) version 16 software for frequencies and percentages.

\section{RESULTS}

Total number of deliveries during the 3-yr. study period was 2491 , of which preterm babies (< 37 weeks) constituted 517 (20.75\%). The inborn preterms of the gestation $28^{+0}-33^{+6}$ weeks included 126 . The incidence of preterm delivery in $28^{+0}-33^{+6}$ gestation group is 50 per 1000 live births (5.05\%). The total admissions to the NICU during the study period was 1421. Of these, preterm babies of gestational age $28^{+0}-33^{+6}$ weeks who met the inclusion criteria constituted 164 (11.54\%). 3 babies were excluded due to congenital anomalies. 5 babies were excluded due to incomplete data of which 2 were home deliveries. Among the 156 babies included in the study, 87 (55.76\%) were males and 69 $(44.24 \%)$ were females. Male-to-female ratio is 1.26 : 1 . Babies of gestation 33 weeks constituted maximum number (42) (Figure 1).

Mode of Delivery was by normal vaginal in 82 (52.56\%), instrumental in $1(0.65 \%)$ and caesarean section in 73 $(46.79 \%)$. Severe preterm babies constituted 76 (48.72\%) with mean weight $1.29 \pm 0.27 \mathrm{~kg}$, moderate preterm babies constituted $80(51.28 \%)$ with mean weight of $1.72 \pm 0.35 \mathrm{~kg}$. Maximum number of babies were in the weight group 1000 1499 grams (Figure 2). There were 15 sets of twins and one set of triplets.

The total mortality in the study group was 7 (4.48\%). 4 died of sepsis, 2 due to severe birth asphyxia and 1 due to severe respiratory distress syndrome with pulmonary haemorrhage (Table 1). There was no mortality in the 32 - 34 weeks group.

The morbidities of the preterm babies in different gestational age groups are shown in Table 2. Respiratory distress syndrome (RDS) was present in 91 babies (58.33\%) of the study population. Among those with respiratory distress, 70 (76.92\%) received Oxygen, 49 (53.85\%) received CPAP and 19 (20.87\%) received mechanical ventilation. Birth asphyxia was seen in 4 babies (2.56\%). Resuscitation with bag and mask ventilation or intubation was done in 38 (28.36\%), of which 30 babies were in the 28 - 31 weeks gestational age group.

Among the $23(14.74 \%)$ babies who had apnoea, 20 $(86.95 \%)$ were in the 28 - 31 weeks gestation. Blood culture positive Sepsis was seen in $27.56 \%$, Meningitis in $8.97 \%$, Necrotising enterocolitis in $7.69 \%$, Acute Kidney injury in $8.97 \%$, Seizures in $5.13 \%$, IVH in $4.49 \%$ and Retinopathy of Prematurity in $12.82 \%$ of the study population.

The management during hospitalisation is summarised in Table 3. Oxygen was started in 100 (64.10\%) babies. 60 $(36.46 \%)$ babies needed nasal continuous positive airway pressure (CPAP) babies. Surfactant was given in 39 (25\%) babies, of whom 27 babies were in the $28^{+0}-31^{+6}$ weeks gestational age group (Figure 3). 26 (16.67\%) babies required mechanical ventilation, of which 2 babies developed pneumothorax and 1 baby had chronic lung disease. 3 babies had symptomatic patent ductus arteriosus, of which one needed surgical correction. 
Anaemia requiring blood transfusion was seen in 15 (9.61\%) and Hyperbilirubinaemia requiring phototherapy was present in $99(63.46 \%)$ of study group with no babies needing exchange transfusion.

\begin{tabular}{|c|c|c|}
\hline Gestation (156) & Morbidity (131) & Mortality (7) \\
\hline $28^{+0}-31^{+6}$ weeks & $68(89.47 \%)$ & $7(9.21 \%)$ \\
\hline $32^{+0}-33^{+6}$ weeks & $63(78.75 \%)$ & $0(0)$ \\
\hline Table 1. Gestation Specific Morbidity and Mortality \\
\hline
\end{tabular}

\begin{tabular}{|c|c|c|c|c|}
\hline $\begin{array}{l}\text { Sl. } \\
\text { No. }\end{array}$ & Morbidity & $\begin{array}{c}\text { Total } \\
\text { Babies }\end{array}$ & \begin{tabular}{|c|} 
Severe \\
Preterm (76)
\end{tabular} & \begin{tabular}{|c|} 
Moderate \\
Preterm (80)
\end{tabular} \\
\hline 1 & $\begin{array}{c}\text { Respiratory } \\
\text { distress }\end{array}$ & $\begin{array}{c}91 \\
(58.33 \%)\end{array}$ & $\begin{array}{c}57 \\
(75 \%)\end{array}$ & $34(42.5 \%)$ \\
\hline 2 & Apnoea & $\begin{array}{c}23 \\
(14.74 \%)\end{array}$ & $\begin{array}{c}20 \\
(26.31 \%)\end{array}$ & $3(3.75 \%)$ \\
\hline 3 & Birth Asphyxia & $4(2.56 \%)$ & $3(3.94)$ & $1(1.25 \%)$ \\
\hline 4 & Sepsis & $\begin{array}{c}43 \\
(27.56 \%)\end{array}$ & $\begin{array}{c}22 \\
(28.95 \%)\end{array}$ & $21(26.25 \%)$ \\
\hline 5 & Hypoglycaemia & $\begin{array}{c}7 \\
(4.48 \%)\end{array}$ & $\begin{array}{c}3 \\
(3.95 \%)\end{array}$ & $4(5 \%)$ \\
\hline 6 & $\begin{array}{c}\text { Feed } \\
\text { Intolerance/ } \\
\text { NEC }\end{array}$ & $\begin{array}{c}12 \\
(7.69 \%)\end{array}$ & $\begin{array}{c}9 \\
(11.84 \%)\end{array}$ & $3(3.75 \%)$ \\
\hline 7 & IVH & $\begin{array}{c}7 \\
(4.49 \%)\end{array}$ & $\begin{array}{c}6 \\
(7.89 \%)\end{array}$ & $1(1.25 \%)$ \\
\hline 8 & $\begin{array}{c}\text { Anaemia needing } \\
\text { transfusions }\end{array}$ & $\begin{array}{c}15 \\
(9.61 \%)\end{array}$ & $\begin{array}{c}14 \\
(18.42 \%)\end{array}$ & $1(1.25 \%)$ \\
\hline 9 & Meningitis & $14(8.97 \%$ & $9(11.84 \%)$ & $5(6.25 \%)$ \\
\hline 10 & $\begin{array}{l}\text { Acute kidney } \\
\text { injury }\end{array}$ & $\begin{array}{c}14 \\
(8.97 \%)\end{array}$ & $\begin{array}{c}11 \\
(14.47 \%)\end{array}$ & $3(3.75 \%)$ \\
\hline 11 & ROP & $\begin{array}{c}20 \\
(12.82 \%)\end{array}$ & $\begin{array}{c}16 \\
(21.05 \%)\end{array}$ & $4(0.05 \%)$ \\
\hline 12 & Seizures & $\begin{array}{c}8 \\
(5.13 \%)\end{array}$ & $\begin{array}{c}6 \\
(7.89 \%)\end{array}$ & $2(2.5 \%)$ \\
\hline 13 & \begin{tabular}{c|} 
Hyper- \\
bilirubinaemia
\end{tabular} & $\begin{array}{c}99 \\
(63.46 \%\end{array}$ & $\begin{array}{c}48 \\
(63.16 \%)\end{array}$ & $51(63.75 \%)$ \\
\hline \multicolumn{5}{|c|}{ Table 2. Morbidity Profile } \\
\hline
\end{tabular}

\begin{tabular}{|c|c|c|c|c|}
\hline $\begin{array}{c}\text { Sl. } \\
\text { No. }\end{array}$ & Treatment & Total & $\begin{array}{c}\text { Severe } \\
\text { Preterm }\end{array}$ & $\begin{array}{c}\text { Moderate } \\
\text { Preterm }\end{array}$ \\
\hline 1 & Resuscitation & $\begin{array}{c}38 \\
(28.36 \%)\end{array}$ & $\begin{array}{c}30 \\
(39.47 \%)\end{array}$ & $8(10 \%)$ \\
\hline 2 & Oxygen & $\begin{array}{c}100 \\
(64.10 \%)\end{array}$ & $\begin{array}{c}56 \\
(73.68 \%)\end{array}$ & $44(55 \%)$ \\
\hline 3 & CPAP & $\begin{array}{c}60 \\
(38.46 \%)\end{array}$ & $\begin{array}{c}41 \\
(53.95 \%)\end{array}$ & $19(23.75 \%)$ \\
\hline 4 & Insure & $\begin{array}{c}39 \\
(25 \%)\end{array}$ & $\begin{array}{c}27 \\
(35.53 \%)\end{array}$ & $12(15 \%)$ \\
\hline 5 & $\begin{array}{c}\text { Mechanical } \\
\text { ventilation }\end{array}$ & $\begin{array}{c}26 \\
(16.67 \%)\end{array}$ & $\begin{array}{c}24 \\
(31.58 \%)\end{array}$ & $2(2.5 \%)$ \\
\hline 6 & $\begin{array}{c}\text { Packed cell } \\
\text { transfusion }\end{array}$ & $\begin{array}{c}15 \\
(9.615) \\
7\end{array}$ & $\begin{array}{c}14 \\
(18.42 \%)\end{array}$ & $1(1.25 \%$ \\
\hline 7 & Phototherapy & $\begin{array}{c}99 \\
(63.46 \%)\end{array}$ & $\begin{array}{c}48 \\
(63.16 \%)\end{array}$ & $51(63.75 \%)$ \\
\hline 8 & $\begin{array}{c}\text { Exchange } \\
\text { transfusion }\end{array}$ & 0 & 0 & 0 \\
\hline \multicolumn{4}{|c|}{ Table 3. Management Profile } \\
\hline
\end{tabular}

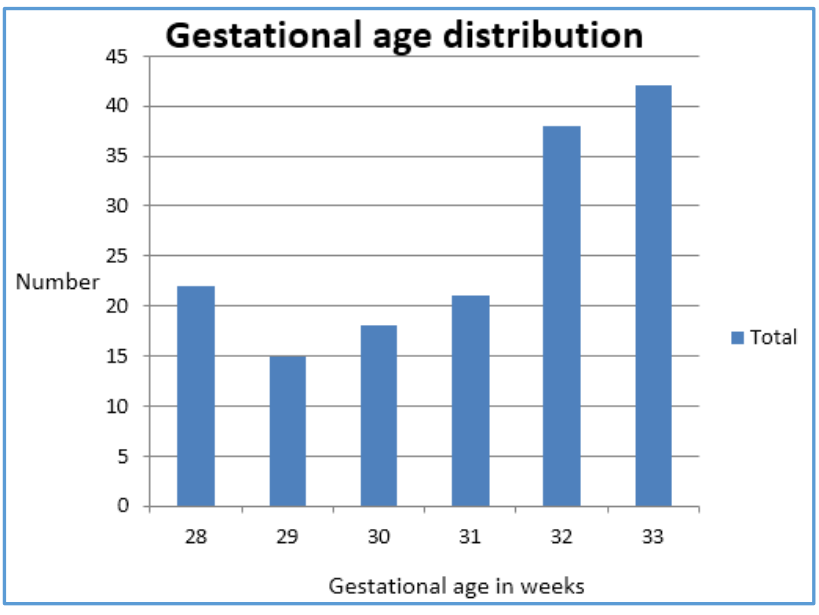

Figure 1

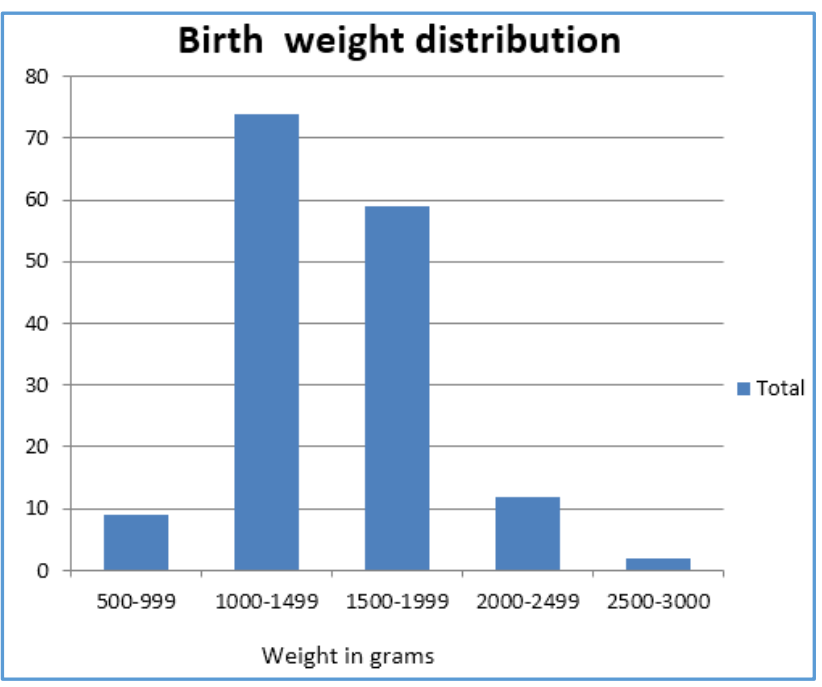

Figure 2

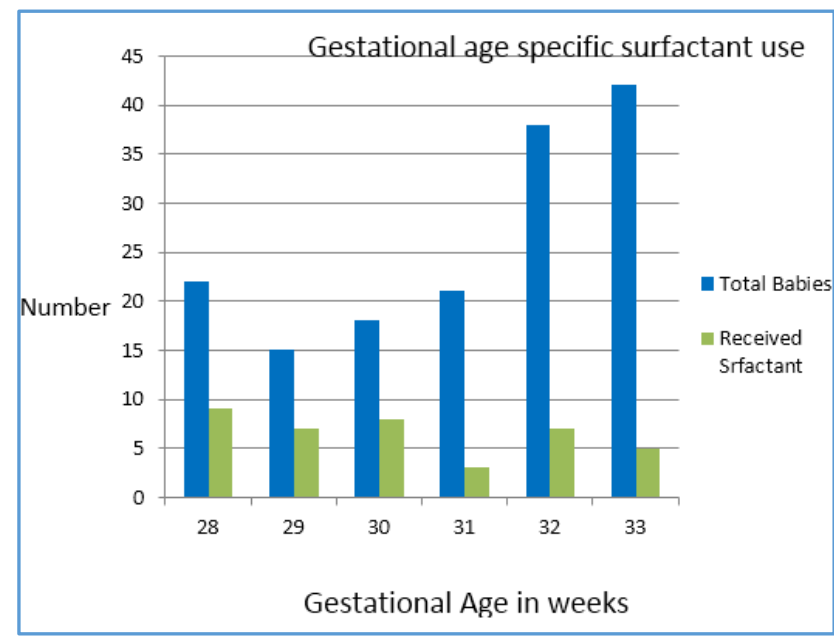

Figure 3. Surfactant Therapy and Gestational Age

\section{DISCUSSION}

Premature births are constantly rising worldwide despite advances in maternal and neonatal care. Preterm birth rates have been reported to range from $5 \%$ to $7 \%$ of all live births in some developed countries, but are estimated to be substantially higher in developing countries.(15) According to the Global Action Report on Preterm Birth by The World Health Organisation- India tops the list of 10 nations 
contributing $60 \%$ of the world's premature deliveries with the maximum number of preterm births, almost $24 \%$ of the total number.(16) In our study the incidence of preterm delivery was $19.55 \%$, almost at par with the studies conducted by Singh $U$ et al and Satija A et al, where they reported an incidence of $20.9 \%$ and $20.4 \%$ respectively.(17,18) The incidence of preterm delivery of the gestation $28^{+0}-33^{+6}$ in our study was 50 per 1000 live births (5.05\%) similar to study by Saheli Misra in which the incidence was 5.28\%.(19)

The mortality rate in our study was (4.48\%) lower than in the study done by Saheli Misra and Ashish Kumar Yadav who had reported a mortality rate of $9.09 \%$.(19) This may be due to early antenatal steroid use in mothers as well as early rescue therapy with surfactant in babies with RDS. Sepsis was the major cause of mortality followed by severe birth asphyxia and respiratory distress syndrome. Jaundice and Respiratory Distress were the most common causes of morbidity. These findings were similar to the studies done by Laxman et al(20) and Srinivas et al.(21) They found that respiratory distress, hyperbilirubinaemia and sepsis were the major causes of morbidity with respiratory distress syndrome and sepsis as the main cause of mortality.

Neonatal Jaundice was the most common morbidity $(63.46 \%)$, but all babies were effectively managed by phototherapy alone. This stresses the importance of implementing practices that protect, promote and support breastfeeding, so as to alleviate this burden. Sepsis still continues to be a major threat in our unit (27.56\%). Strict infection control measures with constant monitoring and surveillance will definitely help to reduce the morbidity due to sepsis.

RDS was a major morbidity (58.33\%) with $75 \%$ in severe preterm and $42.5 \%$ in moderate preterms showing a decreasing trend with increasing gestational age. This is opposite to the study done by Laxman et al,(20) where they noticed a higher incidence in moderate preterm. Only 19 babies required mechanical ventilation among the 91 babies with RDS. Early surfactant therapy and nasal CPAP may be the reasons for less number of babies going for mechanical ventilation. Hussain et $\mathrm{al}(22)$ has studied the outcomes between 28 to 32 weeks gestation and concluded that low cost techniques (antenatal steroids for preterm labour and postnatal use of CPAP therapy) can potentially save the majority of babies in low income countries with minimum inhospital pre-discharge morbidity.

\section{CONCLUSION}

Preterm deliveries are increasing over the years, despite improved antenatal care. RDS and sepsis continue to be important causes of mortality and morbidity in preterm babies. Simple measures to prevent infection can have a major impact on the morbidity. Low cost equipment like bubble CPAP and trained personnel for early surfactant therapy can reduce the morbidity to a greater extent. Up-todate information about the incidence of prematurity, morbidity and mortality from within their regions will help the clinicians to provide accurate counselling and anticipate complications as well as facilitate review of local policies to improve the outcomes.

\section{ACKNOWLEDGEMENTS}

We acknowledge the efforts of our colleagues and staff in conducting this study.

\section{REFERENCES}

[1] Beck S, Wojdyla D, Say L, et al. The worldwide incidence of preterm birth: a systematic review of maternal mortality and morbidity. Bulletin of the World Health Organization 2010;88:31-8.

[2] Jehan I, Harris H, Salat S, et al. Neonatal mortality, risk factors and causes: a prospective population-based cohort study in urban Pakistan. Bull World Health Organ 2009;87(2):130-8.

[3] Fanaroff AA, Stoll BJ, Wright LL, et al. Trends in neonatal morbidity and mortality for very low birth weight infants. Am J Obstet Gynecol 2007;196(2):147.e1-8.

[4] Goldenberg RL, Culhane JF, Iams JD, et al. Epidemiology and causes of preterm birth. Lancet 2008;371(9606):75-84.

[5] Blencowe H, Cousens S, Chou D, et al. Born too soon: the global epidemiology of 15 million preterm births. Reprod Health 2013;10(Suppl 1):S2.

[6] Vohr BR, Wright LL, Dusick AM, et al. Neurodevelopmental and functional outcomes of extremely low birth weight infants in the National Institute of Child Health and Human Development Neonatal Research Network, 1993-1994. Pediatrics 2000;105(6):1216-26.

[7] Shah R, Mullany LC, Darmstadt GL, et al. Incidence and risk factors of preterm birth in a rural Bangladeshi cohort. BMC Pediatr 2014;14:112.

[8] Papile LA, Burnstein J, Burnstein R, et al. Incidence and evolution of subependymal and intraventricular hemorrhage: a study of infants with birth weights less than 1,500 gm. J Pediatr 1978;92(4):529-34.

[9] International Committee for the Classification of Retinopathy of Prematurity. The international classification of retinopathy of prematurity revisited. Arch Ophthalmol 2005;123(7):991-9.

[10] Vidyasagar D. Clinical features of respiratory distress syndrome. In: Stern L, (eds). Hyaline membrane disease, pathogenesis and pathophysiology. New York: Grune and Stratton 1984:97-118.

[11] Jobe AH, Bancalari E. Bronchopulmonary dysplasia. Am J Respir Crit Care Med 2001;163(7):1723-9.

[12] Working Definitions. South East Asia Regional Neonatal-Perinatal Database. World Health Organization (South-East Asia Region) Available fromhttp://www.newbornwhocc.org/pdf/database.pdf. Accessed - February 25, 2016.

[13] Jetton JG, Askenazi DJ. Update on acute kidney injury in the neonate. Curr Opin Pediatr 2012;24(2):191-6.

[14] National Institute for Health and Care Excellence (2010) Neonatal Jaundice (Nice Clinical guideline 98). Available at: http://www.nice.org.uk/guidance/CG98 [Accessed 06/02/2014]. 
[15] Blencowe $\mathrm{H}$, Cousens $\mathrm{S}$, Oestergaard $\mathrm{MZ}$, et al. National, regional and worldwide estimates of preterm birth rates in the year 2010 with time trends since 1990 for selected countries: a systematic analysis and implications. Lancet 2012;379(9832):2162-72.

[16] March of Dimes, PMNCH, Save the Children, WHO. Born too soon: the global action report on preterm birth. Howson CP, Kinney MV, Lawn JE. (eds). World Health Organization. Geneva, 2012.

[17] Uma S, Nisha S, Shikha S. A prospective analysis of etiology and outcome of preterm labour. J Obstet Gynecol India 2007;57(1):48-52.

[18] Satija A, Satija V, Kaur J, et al. Prospective analysis of preterm labour: its etiology and outcome. Int J Basic Appl Med Sci 2014;4(2):70-7.
[19] Saheli M, Kumar YA. A study of adverse outcome in early and moderate preterms. Indian Journal of Public Health Research \& Development 2016;7(1):17-22.

[20] Browen JR, Gibson FL, Hand PJ. Educational outcome at 8 years for children who were born extremely prematurely: a controlled study. J Paediat Child Health 2002;38:438-44.

[21] Bolisetty S, Legge N, Bajuk B, et al. Preterm infant outcomes in New South wales and the Australian capital territory. J Paediatr Child Health 2015;51(7):713-21.

[22] Parappil H, Rahman S, Salama H, et al. Outcomes of $28+1$ to $32+0$ weeks gestation babies in the state of Qatar: finding facility-based cost effective options for improving the survival of preterm neonates in low income countries. Int J Environ Res Public Health 2010;7(6):2526-42. 